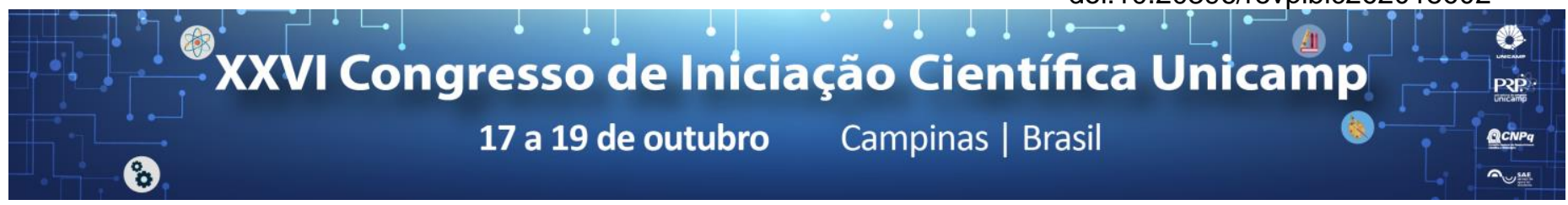

\title{
Quem pode usar saia? Uma etnografia sobre diversidade de gênero em terreiros de candomblé.
}

\section{Homero Dantas Ragnane, Isadora Lins Franca.}

\begin{abstract}
Resumo
Essa pesquisa busca compreender como são formadas as noções de gênero em dois terreiros de candomblé situados nas cidades de Campinas e São Paulo. Ao acompanhar etnograficamente as dimensões da divisão do trabalho realizado antes das festas públicas e a indumentária ritual no que concerne seu potencial generificador, busca-se compreender como se produzem essas noções de gênero e como se constroem espaços e atividades que são generificados ao mesmo tempo em que generificam. Também é escopo dessa pesquisa como o povo-de-santo concebe a presença de pessoas trans ${ }^{*}$, nos terreiros e a, consequente, discussão acerca da imagem dos terreiros enquanto espaços historicamente qualificados como acolhedores de populações marginalizadas tais quais as LGBTQI.
\end{abstract}

\section{Palavras-chave: Religiões de matriz africana; Estudos de gênero, Candomblé}

\section{Introdução}

Rosaldo (2012) busca estabelecer o argumento que estabelece os papeis de homens e mulheres como produto direto da ação humana em sociedades que são construídas historicamente. A autora, assim como outras nesse debate, aponta a influência da categoria gênero na organização de diversas instituições humanas, bem como a relação dialógica entre esta categoria e a sociedade. Rosaldo também aponta que papeis de gênero não devem ser pensados a partir de universalismos ou essencialismos, mas são informados por um conjunto complexo de símbolos que são forjados contextualmente e em relação a outros fatores. Scott (1994) aponta para outra dimensão da questão. Para ela, gênero se constitui enquanto uma relação social baseada nas diferenças percebidas entre os sexos e que guarda em si dinâmicas de poder. Nesse sentido, Joan Scott estabelece gênero como o saber, no sentido dado por Foucault (1980), a respeito das diferenças sexuais. Através dos argumentos de ambas as autoras é possível observar que as reflexões passam pela conjugação da construção do saber às relações de poder engendradas nas tramas da sociedade. Essas discussões têm como pano de fundo o contexto ocidental no qual estão inseridas as comunidadesterreiros. Refletindo acerca dessas ideias, a questão se torna: como os mecanismos de formação de gênero operam nos terreiros? Levando em consideração a fama dos terreiros enquanto espaços de poderosa liberdade para as diversidades marginalizadas, como esses espaços recebem pessoas trans ${ }^{*}$ ou corpos que desafiem a heteronorma?

\section{Resultados e Discussão}

O trabalho de campo realizado aqui se desdobrou em dois momentos: o primeiro deles foi o de observação das festas públicas onde foi possível identificar e explorar algumas questões sobre a construção de gênero através da indumentária e do transe ritual. Posteriormente a esse momento foi possível acompanhar algumas funções (atividades que preparam as festas públicas e ali perceber outra dimensão dos processos de subjetivação de gênero: o trabalho. Constatou-se a existência de espaços que operavam enquanto marcadores de gênero $\mathrm{e}$ atividades que eram generificadas à medida que também generificavam aqueles que as realizavam. Além disso, em um dos terreiros acompanhados havia uma quantidade incomum de pessoas trans* ${ }^{*}$ que foi fundamental para as questões dessa pesquisa.

No que tange a discussão teórica empreendida por essa pesquisa, a bibliografia gravitou em torno de questões relacionadas à economia das sexualidades nos terreiros, questões que foram também sugeridas pelo campo, como a figura do adé tão consolidada nas discussões acadêmicas e ainda hoje tão presente nos terreiros de candomblé. Nesse sentido, foi possível explorar com mais profundidade a relação entre o transe e as normas de gênero e sexualidade. E consequentemente, como essa tríade está em profunda dinâmica de retroalimentação.

\section{Conclusões}

A partir dessa pesquisa foi possível concluir que apesar de existirem elaborações singulares aos terreiros em alguns sentidos, as dinâmicas de gênero e sexualidade operam nesses espaços de formas parecidas àquelas da sociedade abrangente. A particularidade dos terreiros de candomblé está no tratamento ritual dessas dinâmicas e, consequentemente, a reelaboração de sentido dessas noções. Também foi possível questionar e problematizar a fama dos terreiros enquanto uma espécie de paraíso das diferenças ao observar que 0 princípio heteronormativo existente na sociedade abrangente também se instalou nos terreiros através do diálogo com outras esferas sociais. Portanto, os terreiros não são espaços de liberdade irrestrita para sujeitos que desafiem essa norma como pessoas trans*, por exemplo.

\section{Agradecimentos}

Agradeço ao povo de santo que contribuiu para a realização dessa pesquisa. Agradeço também à Prof ${ }^{a}$ Dra. Isadora Lins França pela orientação sensível, compreensiva, laboriosa e minuciosa durante todo 0 curso desse trabalho. Por fim, agradeço ao CNPq pelo apoio sem o qual essa pesquisa não seria possível.

FOUCAULT, Michel. História da sexualidade 1: A vontade de saber. 3. ed Rio de Janeiro: Graal, 1980.

ROSALDO, M. Usos e abusos da antropologia: reflexões sobre o feminismo e o entendimento intercultural. In: Horizontes Antropológicos, 1 (1), 2012.

SCOTT, Joan. Preface a gender and politics of history. In: Cadernos Pagu, n. 3, Campinas, SP, 1994. 